\title{
Legal Education Issues in Globalization Context
}

\author{
Olga Kravchenko *, Dilovar Naskov \\ Law Department, Russian-Tajik Slavonic University, M.Tursunzoda str., 30, Dushanbe, 734025, Tajikistan
}

\begin{abstract}
The authors consider the problems of legal education in the context of globalization. It is noted that an important role is attributed to legal education when we talk about legal personality development. In this case, it is necessary to distinguish between the concepts of legal education and legal upbringing. In addition, the legal socialization of minors can facilitate the development of legal knowledge. According to the authors consideration of the problems referring to the legal education is associated with the processes of modernization of legal socialization, which should begin with the solution of problems of legal education. In turn, legal education can become a powerful tool and a way to counteract such antisocial phenomena as terrorism and extremism that bring threat to peace and the whole of mankind. In the context of globalization, legal education is focused on new legal values that are established in national and international legislation.
\end{abstract}

\section{Introduction}

Nowadays, the State and society are interested in the legal decency not only of minors but also of society as a whole. In the context of globalization of social life and the need to counter the threat of extremism and terrorism the legal education fulfills an important historical mission in combination with other forms of education throughout the world.

The latter confirms the idea that legal education is a multifaceted and complex process, expressed in various forms and combinations. This is a complex and important component of the ideological function of any State, therefore not all definitions of this concept reflect the essence of it.

Currently, the legal education is a complex, continuous process aimed at solving various issues:

- to develop legal awareness, which is the main part of social consciousness;

- to facilitate the development of scientific knowledge and understanding of law;

- to ensure legal culture as a derivative of legal awareness;

- to develop the assurance in the correctness and fairness of enactment and the habit of legal behavior [1].

\section{Results and Discussion, Findings}

The role of legal education in the development of legal personality is also important, since, according to I.Yu. Blyasov and N.V. Byakov 'decency presupposes the relevant level of personality development, which differs from the concept of legal upbringing, which represents a potential level of personality development and a zone of its closest development. Upbringing is the possibility for personal development' [2]. In other words, with a low level of personal development of adolescents one cannot talk about their legal decency and their legal illiteracy leads to legal nihilism. The latter is defined by N.I. Matuzov and A.V. Malko as 'a disrespectful attitude towards the law, legislation, regulation, legal order; legal discourtesy of a certain part of population is the reason for its occurrence'. In this regard O.A. Dolgopolov considers overcoming of legal nihilism and legal barbarism, as antipodes of legal consciousness and legal culture, be a more specific and comprehensive task of legal education [3].

Thus, if the process of development of a legal personality involves ascribing a person the characteristics of a complete legal type and manifesting his activity in social and legal practice, then legal decency reveals the qualities of a person according to the level of mastering his/her legal knowledge. In addition, the legal socialization of minors can also ensure the development of legal knowledge. Therefore, today the consideration of the problems of legal education is associated with the processes of modernization of legal socialization. According to A.S. Evdokimova 'current legal socialization of citizens needs modernization, the main ways of which may result in further development of civil society institutions, the establishment of legal personality, as well as legal education' [4].

The implication is that the modernization of legal socialization should begin with problem solution of legal education, since the development of the institutions of civil society and legal personality has always depended and will depend on the effectiveness of legal education. Today the legal education touches upon the issues relating to all fields of public life caused by the process of law reforming, legal relations, establishment of new legal thinking, search for the causes of deviations and defects in behavior. In addition, today, the legal education plays a key role in the civil development of an

Corresponding author: o_kravchenko_08@mail.ru 
individual. The task of the establishment of civic conscience of the younger generation is one of the priorities of the development of any society in accordance with the needs of stability and continuity, consolidation and social harmony in it [5]. Civil development or establishment of an individual is connected with the concept of citizenship. By civic consciousness we understand the moral position expressed in the sense of duty and responsibility of a person to society, the State, family, as well as in his or her readiness to defend and protect against all encroachments of its rights and interests [6]. Moreover, it may result in some type of counteraction to various antisocial and negative phenomena in the society, including the involvement of youth and minors in terrorist organizations. Terrorism is a constant companion of mankind, one of the most dangerous and hardly predictable phenomena of our time, taking on increasingly diverse forms and threatening scale [7]. In the opinion of A.M. Hamidova 'the distorted formation of personality and faulty upbringing make the minors choose the criminal path' [8]. The author also notes that 'a minor offender participating in a terrorist crime becomes a victim for the reason that under the influence of adults he/she receives an antisocial attitude, i.e. a willingness to commit crimes against public security. $\mathrm{He} / \mathrm{she}$ is a victim that is why when performing acts of terrorism, as a rule, he/she performs the most dangerous actions, thereby exposing himself/herself to the increased risk following the adult's will' [8]. Terrorism is the danger of the century. It has become a problem for all countries worldwide; to eliminate it we must fight together. In his speeches the Founder of Peace and Concord, the Leader of the Nation, the President of the Republic of Tajikistan Emomali Rahmon repeatedly dwelled on this threat and described terrorism as 'a terrible and disgusting phenomenon', 'which often manifests itself under the religious and Mazhabi slogans, however, it has nothing to do to the sacred religion of Islam'. In his opinion, this is a 'plague of the century, representing a danger for humanity no less than nuclear weapons' [9]. In this regard, today, international terrorist and extremist organizations such as the Muslim Brotherhood, Hizbut tahrir al-islomiy, Al-jihad International, Al-Qaeda, Movement of East Turkestan, Islamic Party of Turkestan (former Islamic Movement of Uzbekistan), Taliban movement, Lashkar-e-Toiba, Islamic group, Islamic organization of Pakistan, Tablighi Jamaat, missionary religious organization Tablighi Jamaat, Freedom of Tajikistan, Salafizm and other are closely associated with the infamous Al-Qaeda. [10]

According to the latest data, announced by the Prosecutor General's Office of the Republic of Tajikistan in March 2016, about 1,100 Tajik citizens are fighting in the Syrian and Iraqi side of the terrorist organization ISIS (Daesh, Islamic State, IS). At the same time, in January 2015, the head of the Tajik jihadists in the Taba province of Ar-Raqqah in Syria, Nusrat Nazarov, known as Abu Kholid Kulobi, said in his video message that the number of Tajiks in ISIS is over 2,000 people. Among them are recruited minors and youth. In the context of the problem related to threat of life- sustaining activity of the State and people it is important to strengthen the role of legal education among minors, because by influencing the mind of a minor legal education can become a powerful tool and a way to counteract such antisocial phenomena as terrorism and extremism that threaten the world and all mankind. In this perspective, an integrated approach to the legal education is important, i.e. the implementation of the process of legal education in combination with other forms of educational influence (patriotic, political, moral, ecological, military education, etc.) both in the process of training and in time of extracurricular work on legal and civic education. Besides, the acquisition of citizenship is facilitated by social and legal experience acquisition by minors that results in their socialization as the result of the civil establishment of an individual may be the effective use of experience gained in different life situations.

It should be noted that legal education is not a spontaneous impact on the perception of legal values and norms by a person, but an organized, systematic, purposeful activity aimed at building the sense of justice of the members of society. If we adhere to this view, then the scientists who have studied the problems of the theory of legal education have not made and significant changes in the concept of the educational process. In another words, the point of view on the legal education concept which existed in the Soviet legal literature remained the same.

In the set of lectures on the General Theory of the Law published under the editorship of V.K. Babaev it is said that 'legal education is a planned, controlled, organized, systematic and purposeful process of influencing the consciousness, the psychology of citizens with the totality of the diverse legal forms, means and methods available in the arsenal of modern legal activity, with the aim to develop deep and sustainable legal knowledge, beliefs, needs, values, habits of legal behavior'. The same thoughts are contained in the book of R.Sh. Sovtivdiyev Problems of the Theory of State and Law according to which 'legal education is a systematic, organized, purposeful and regulated activity of state bodies and institutions, organizations, public associations, officials and citizens aimed at raising the level of legal knowledge and legal culture of the society'. The same approach is followed by E.A. Darius who in his study writes that 'legal education is a purposeful, organized and systematic influence on the personality, establishing legal awareness, legal attitudes, skills and habits of active legal behavior and legal culture [11]. E.M. Gavrish also notes that 'legal education, in fact, is an organized, systematic, purposeful influence on the individual, forming legal awareness, legal attitudes, habits and habits of legal behavior' [12]. I.V. Klochko, referring to this problem, writes that 'legal education is primarily a systematic and purposeful activity of state bodies and public organizations which has a certain influence on the legal consciousness and behavior of individuals, on their legal upbringing, on social and economic structure, moral and legal atmosphere, etc. conditions, prerequisites and factors that influence the legal education of an 
individual' [13]. According to V.N. Baranova 'legal education is carried out by special subjects. Organizations, bodies, authorized officials, teachers, scientists, teachers, parents and others can be called the subjects of the legal education. Individuals or certain groups of the population refer to the object of education'. T.M. Pochtar believes that the activities of these subjects are implemented through the legal education, i.e. the direct acquisition of knowledge. Legal education is a 'method of external expression and transfer of theoretical legal material to the object of education' [14]. It all adds up to the idea that even the post-Soviet literature preserves the notion, goals, tasks and elements of legal education defined during the Soviet period of time. However, this does not mean that for the entire period of its history the concept of legal education has not changed, since along with the development of the society, public institutions had also developed. In this regard, today the content of the legal education of minors is focused on new legal values and norms established in both national legislation and international norms and standards. In addition, the goals and objectives of legal education are now described in accordance with the social need determined by the market conditions when the preference is given to a person with the profound understanding of law.

The effectiveness of mastering the basic provisions of legislation, developing a sense of deep respect for law in many ways depends on the availability of legal education and the implementation of its functions. In the opinion of F.A. Lapumanski legal education performs two functions simultaneously:

1. Development of legal awareness and certain behavior.

2. Overcoming the deformation of the sense of justice of persons who reject the proper and necessary [15]. Of course, here we are talking about the general direction and application of the functions of the legal education. However, the functions of legal education may be described as a system, consisting of functional elements. The main functions are: regulative, protective, cognitive, communicative, ideologically educational, preventive, applicable, prognostic and heuristic [16]. The functions of legal education are interrelated and, in particular, they carry out important tasks in the development of legal awareness of an individual. A leading role in the formation of the world view and understanding of the legal reality is played by cognitive function [17].

One cannot fail to note the importance of the regulative function of legal education, as this function affects all citizens' behavior, ensures the work of the legal system and creates a fundamental legal order [18]. The interactive methods of influencing the minors' legal conscience are also developing and being used.

In addition, today, as before, there are the main items identified regarding legal education: legal education, legal training, legal propaganda, legal agitation, and legal self-education. These directions are aimed not only at the development of the legal consciousness and legal culture of an individual, but also create a certain prerequisite for the establishment of new norms and principles of the law, democracy, legal foundations of the State and, in general, the development of the civil society; however, the priority is given to the legal upbringing of a person. Nevertheless, we do not deny the value and significance of other social norms that determine the behavior of a person in the process of its development, since along with the legal regulation of behavior, other processes of educational influence also occur. And no matter what subjective reasons are given, the person is to blame his or herself in case he/she commits a crime. And why? Probably it happens because he/she does not know the legislation, does not respect the law, is dishonest, envious, ill-mannered, etc. [19].

Therefore, it is no accident that in the Decree of the President of the Republic of Tajikistan On Legal Policy and Legal Education of Citizens of the Republic of Tajikistan of 9 April 1997, No. 691 [20] and the Decree of the Government of the Republic of Tajikistan On Some Measures for Improvement of Citizens' Legal Education and Legal Work in the Republic of 22 August 1997, No. 383 [21] the importance of the aspect of ideological and educational work and its role in the development of legal awareness, the prevention of violations among the younger generation is indicated. Moreover, in the messages, reports, speeches of the President of the Republic of Tajikistan [22] decisions of the Government of the Republic of Tajikistan the development of a modern person is defined as one of the main tasks not only of the state bodies, but also of the public as a whole. In particular, referring to this issue, the President of the Republic of Tajikistan E. Rahmon in his address to the Parliament of the country as of 26 April 2013 noted that '.. our most important task is the education of a competent and patriotic person with a high social responsibility, with modern knowledge, and, finally, an individual who is able to cognize the complex processes of today's world' [23].

\section{Conclusion}

Thus, the analysis of the literature shows that the issues of legal education have always been payed much attention in the theoretical, methodological, and in the conceptual sense. The problems of modern understanding of legal education are also studied in the works of scientists on the basis of which one can conclude that there is pluralism in the views on the education of legal awareness in the context of globalization of public life based on the principles of democracy and humanism, universal values, respect for cultural heritage, etc.

Legal education is a purposeful process that aims to assimilate and apply the norms of law in the daily life of an individual which is carried out by agents of legal education (family, school, public authorities, etc.).

In addition, the essence and tasks of the legal education consist in the development and establishment of legal consciousness of an individual with his ultimate goal, i.e. the legal development of an individual. At the same time, it is impossible to separate legal education from the process of legal socialization as it is impossible to imagine one without another. 


\section{References}

1. V.V. Popov, Legal Education as an Indispensable Prerequisite for the Development of the Sense of Justice, Psychopedagogy in Law Enforcement Authorities, 1 (13), 10-11 (2000)

2. I.Yu. Bliasova, N.V. Byakova, Characteristics of Legal Upbringing of Modern Adolescents, Vestnik of Chelyabinsk State University, 23 (378), 11 (2015)

3. O.A. Dolgopolov, Establishment of Legal Education in Modern Russia: author's abstract. Thesis of the Candidate of Juridical Sciences. (Ryazan, 2004)

4. A.S. Evdokimov, The Role of Legal Culture in the Process of Legal Socialization of Personality, Bulletin of Novgorod University (Novgorod, 2006)

5. Yu. A. Yakusheva, G.Kh. Batynov, Children's Law School: Topicasl Issues of Legal Education of Minors: Methodical Recommendations, (Surgut: Publishing house of Budgetary Institution of the Khanty-Mansiysk Autonomous Okrug-Ugra Methodological Center for the Development of Social Services, 2013)

6. K.D. Gulyaeva, Modern Forms of Work with Students on the Formation of Citizenship in General Public School, Childhood Safety as a Legal and Social and Pedagogical Concept: Materials of III All Russia scientific-practical. Conf. with the international participation of students, masters, graduate students, teachers and specialists in the framework of the Week of Science in the Deaprtment of Legal and Social and Pedagogical formation of PSPU (April 25-28, 2016, Perm, Russia)

7. M.A. Miloslavskaya, The main causes of terrorism, Scientific Problems of Human Research, 5, 190-196 (2012)

8. A.M. Hamidov, Conditions Ensuring the Involvement of Minors in Terrorism, System Technologies, 1 (6), 128 (2013)

9. E. Rahmon, President's Address of the Republic of Tajikistan Majlisi Oli of the Republic of Tajikistan of 20 January 2016, Retrieved from: http: //www.president.tj/en/node/10587

10. Fundamentals of Countering Terrorism and Extremism under the Legislation of the Russian Federation and the Republic of Tatarstan: An Information and Reference Manual on the Prevention of Extremism and Terrorism (Dushanbe, 2017)

11. E.A. Darius, Legal Education in the Context of Social Education, Russian State Social University, 10, $143-147$ (2010)
12. E.M. Gavrish, Legal Consciousness as an Element of Legal Culture of Schoolchildren, Pedagogical Education in Russia (Ekaterinburg, 2012)

13. I.V. Klochko, Pedagogical Conditions of Education of Legal Consciousness of Older Pupils: Activity Approach: Thesis of the Candidate of Pedaagogical Sciences. 13.00.01. (Vladimir, 2014)

14. T.M. Pochtar, Legal Education in Pedagogical Universities: Issues of Methodology: Thesis of the Candidate of Juridical Sciences. 12.00.01. (M., 2000)

15. F.A. Lapushansky, Criminological Problems of Prevention of Youth Offenses (experience of specific social study). (Kiev: Science. dumka, 1986)

16. O.V. Adaeva, S.V. Sinyakin, Tasks and Functions of Legal Education, Issues of Modern Jurisprudence: proceedings on the materials of LXIII Intern. Scientific and Practical. Conf., Novosibirsk: SibAK, 7 (58), 52-55 (2016)

17. V.V. Strelyaeva, Legal Education in the Conditions of development of the rule of law: Thesis of the Candidate of Juridical Sciences. 12.00.01. (M., 2006)

18. O.V. Adaeva, S.V. Sinyakin, Tasks and Functions of Legal Education, Issues of Modern Jurisprudence: proceedings on the materials of LXIII Intern. Scientific and Practical. Conf. Novosibirsk: SibAK, 7 (58), 52-55 (2016)

19. O.A. Vorobyov, Legal Education of Minors, Izv. Of Russian State Pedagogigal University named after A.I. Herzen, 22, 171-173 (2006)

20. On Legal Policy and Legal Education of Citizens of the Republic of Tajikistan: Decree of the President of the Republic of Tajikistan of 9 April. 1997, No. 691, Decisions of the President and Government of the Republic of Tajikistan. (Dushanbe, 1997)

21. On Some Measures to Improve the Legal Education of Citizens and Legal Work in the Republic: Decree of the Government of the Republic of Tajikistan on 22 August 1997, No. 383, Decisions of the President and Government of the Republic of Tajikistan. (Dushanbe, 1997)

22. E. Rahmon, Address of the President of the Republic of Tajikistan to the Parliament of the Republic of 20.04.2012, Retrieved from: http: // www.president.tj

23. E. Rahmon, Address from the President of the Republic of Tajikistan to the Parliament of the Republic of 26.04.2013, Retrieved from: http: // www.president.tj 